\title{
Peran Adversity Quotient Peserta Didik Kelas VIII SMP Tipe Climber dalam Pemecahan Masalah Matematis di Masa Pandemi Covid-19
}

\author{
Tiara Kusumastuti ${ }^{1}$, Ishaq Nuriadin ${ }^{2}$ \\ ${ }^{1,2}$ Program Studi Pendidikan Matematika, Fakultas Ilmu Pendidikan, Universitas Muhammadiyah Prof. Dr. Hamka, \\ Jl. Tanah Merdeka No 20, Kota Jakarta Timur, DKI Jakarta, Indonesia \\ tiarakusumastuti@gmail.com
}

\begin{abstract}
the government has made a policy for all schools to conduct online learning. This study aims to analyze the role of the adversity quotient of climber type VIII junior high school students in solving mathematical problems during the covid-19 pandemic. The sample in this study was class VIII-B at SMP Taman Harapan 1 Bekasi. The results showed that students with a climber type AQ sometimes made small mistakes and had difficulty solving mathematical problems, however, students with a climber type AQ still tried to solve problems on the questions well and were able to fulfill all problem-solving indicators. So that the climber type AQ plays a role in solving students' mathematical problems.
\end{abstract}

Keywords: climber, problem solving, role.

\begin{abstract}
Abstrak
Pada saat ini virus covid-19 sedang menggemparkan dunia. Semenjak virus ini menyebar hampir ke seluruh dunia, pemerintah memberikan kebijakan bagi seluruh sekolah untuk melakukan pembelajaran secara daring. Penelitian ini bertujuan untuk menganalisis peran adversity quotient peserta didik kelas VIII SMP tipe climber dalam pemecahan masalah matematis di masa pandemi covid-19. Sampel dalam penelitian ini adalah kelas VIII-B di SMP Taman Harapan 1 Bekasi. Instrumen yang digunakan dalam penelitian ini berupa tes kemampuan pemecahan masalah matematis dan angket AQ. Hasil penelitian menunjukkan bahwa terdapat 15 peserta didik dengan AQ tipe climber sedangkan 5 peserta didik lainnya memiliki AQ tipe camper. Hasil penelitian menunjukkan bahwa peserta didik yang memiliki AQ tipe climber terkadang melakukan kesalahan kecil dan mengalami kesulitan saat memecahkan masalah matematis meskipun begitu peserta didik dengan AQ tipe climber tetap berusaha untuk menyelesaikan masalah pada soal dengan baik dan mampu memenuhi semua indikator pemecahan masalah. Sehingga AQ tipe climber berperan dalam pemecahan masalah matematis peserta didik.
\end{abstract}

Kata Kunci: climber, pemecahan masalah, peran.

Copyright (c) 2021 Tiara Kusumastuti, Ishaq Nuriadin

Corresponding author: Tiara Kusumastuti

Email Address: tiarakusumastuti@gmail.com (Jl. Tanah Merdeka No 20, Jakarta Timur, Indonesia

Received 29 June 2021, Accepted 10 July 2021, Published 15 August 2021

\section{PENDAHULUAN}

Matematika yang merupakan dasar perkembangan ilmu menjadikan ilmu matematika penting untuk kita pelajari. Matematika merupakan salah satu mata pelajaran yang memegang peranan penting dalam menyukseskan program pendidikan karena merupakan mata pelajaran wajib mulai dari sekolah dasar hingga sekolah menengah atas (Naimnule, Kartono, \& Asikin, 2020). (NCTM, 2000) mengemukakan bahwa terdapat lima kemampuan matematik yang menjadi standar dalam pembelajaran matematika, yaitu problem solving (pemecahan masalah), reasoning and proof (penalaran dan pembuktian), communication (komunikasi), connections (koneksi), dan representations (representasi). Di negara kita sendiri, Indonesia memiliki kemampuan matematika yang masih sangat rendah dibandingkan negara lain. 
Berdasarkan hasil survey tiga tahunan Programme for Internasional Student Assesment (PISA) untuk rata-rata skor matematika peserta didik Indonesia dari tahun 2003 hingga tahun 2018 (OECD, 2019) ditunjukkan pada tabel dibawah ini.

Tabel 1. Peringkat Skor Matematika Indonesia pada PISA

\begin{tabular}{|c|c|c|c|}
\hline Tahun & Skor & Peringkat & Negara \\
\hline 2003 & 360 & 38 & 40 \\
\hline 2006 & 391 & 50 & 57 \\
\hline 2009 & 371 & 61 & 65 \\
\hline 2012 & 375 & 64 & 65 \\
\hline 2015 & 386 & 63 & 70 \\
\hline 2018 & 379 & 72 & 78 \\
\hline
\end{tabular}

Sedangkan survey empat tahunan The Trends Internasional Mathematics and Sciense Study (TIMSS) tahun 2015, menunjukkan bahwa Negara Indonesia berada pada peringkat ke 44 dari 49 negara peserta dengan skor perolehan rata-rata 397 (Abdiyani, Khabibah, \& Rahmawati, 2019). Berdasarkan hasil survey PISA dan TIMSS di bidang matematika dapat ditarik kesimpulan bahwa rata-rata skor matematika peserta didik di Indonesia masih berada dibawah rata-rata skor internasional.

Pemecahan masalah merupakan kemampuan seseorang dalam menggunakan pengetahuannya dan pengalamannya yang sudah dimilikinya untuk menemukan solusi dari apa yang sedang dihadapi (Eviyanti, Surya, Syahputra, \& Simbolon, 2017). Sedangkan menurut (Nuramalina, Hendrayana, \& Khaerunnisa, 2020) pemecahan masalah merupakan suatu aktivitas mental atau kognitif yang kompleks yang disertai sejumlah proses menggabungkan konsep-konsep atau aturan matematis yang telah dimilikinya. Peneliti menyimpulkan bahwa pemecahan masalah adalah cara seseorang untuk mencari solusi dari suatu masalah yang sedang dihadapi berdasarkan pengetahuan dan pengalaman yang dimilikinya. Apabila guru membiasakan memberikan soal pemecahan masalah kepada peserta didik saat pembelajaran, maka peserta didik akan terbantu dalam mempelajari bagaimana cara menyelesaikan persoalan dan peserta didik akan mengetahui bahwa matematika merupakan ilmu logis dan banyak digunakan dalam kehidupan sehari-hari (Hanifah \& Nuraeni, 2020).

Menurut Polya terdapat 4 indikator pemecahan masalah, yaitu: (1) memahami masalah, (2) merencanakan strategi pemecahan masalah, (3) menerapkan strategi pemecahan masalah, dan (4) meninjau kembali. Setiap peserta didik memiliki strategi yang berbeda untuk memecahkan suatu masalah matematis. Sejalan dengan pendapat (Widyastuti, 2015) yang menyatakan bahwa setiap peserta didik dalam menyelesaikan masalah matematis memiliki cara yang berbeda-beda sesuai dengan karakteristiknya masing-masing. Peserta didik memiliki kesulitannya masing-masing dalam memecahkan suatu masalah dan memiliki cara tersendiri dalam menghadapi masalah. Kemampuan peserta didik dalam mengubah kesulitan yang dihadapi menjadi suatu tantangan yang dapat diselesaikan dengan baik dikenal dengan Adversity Quotient (AQ).

Menurut Stoltz dalam (Isnaini Handayani \& Afifah Fitria Ramadhani, 2020) Adversity Quotient adalah kecerdasan dalam mengatasi kesulitan. Adversity quotient adalah respon seseorang untuk 
bertahan terhadap kesulitan atau masalah dalam usahanya mencapai kesuksesan dengan memanfaatkan potensinya (Juwita, Roemintoyo, \& Usodo, 2020). Sedangkan menurut (Yanti, Koestoro, \& Sutiarso, 2018) adversity quotient adalah penilaian yang mengukur bagaimana respons seseorang terhadap suatu masalah dapat diberdayakan menjadi sebuah peluang. Dengan kata lain adversity quotient adalah kecerdasan untuk menghadapi hambatan atau kesulitan dalam hidupnya. Pada pembelajaran matematika, AQ peserta didik digunakan untuk melihat sejauh mana peserta didik dalam mengatasi kesulitan tersebut. Stoltz dalam bukunya mengungkapkan bahwa terdapat 3 tipe dalam Adversity Quotient yaitu tipe quitter (seseorang yang mudah menyerah), camper (seseorang yang mudah merasa puas), dan climber (seseorang yang selalu terus berusaha).

Seorang climbers akan merasa tertantang apabila menemukan soal pemecahan masalah yang sulit. Seorang climbers memiliki kemampuan Tangguh dalam menghadapi tantangan yang hadir kepadanya (Purwasih, 2019). Sejalan dengan (Stoltz, 2018) yang mengatakan bahwa tipe climber meyambut baik tantangan-tantangan, dan mereka hidup dengan pemahaman bahwa ada hal-hal yang mendesak dan harus segera dibereskan. Ketika disaat orang lain memiliki pemikiran bahwa dia tidak dapat menyelesaikan persoalan tersebut tetapi berbeda dengan orang yang memiliki AQ tipe climber yang memiliki pemikiran dan harapan yang besar bahwa dia mampu menyelesaikan persoalan yang sedang dihadapi.

Pada bulan Desember 2019, dikabarkan terdapat sebuah virus yang muncul dan menyerang penduduk China, mulai dari balita hingga lansia. WHO (World Health Organization) atau Badan Kesehatan Dunia menjadikan wabah ini sebagai pandemi global pada tanggal 11 Maret 2020 (Asmuni, 2020). Virus ini dinamakan virus corona atau dikenal dengan istilah COVID-19 (Coronavirus Desease 2019). Virus ini kemudian menyebar ke berbagai belahan dunia lainnya, termasuk Indonesia. Berdasarkan data yang diperoleh, pada tanggal 28 Juni 2021, jumlah yang terpapar covid-19 di Indonesia mencapai 2.135 .998 orang dan yang meninggal karena terpapar covid-19 mencapai 57.561 orang. Sedangkan jumlah yang terpapar covid-19 di dunia mencapai 179.686.071 orang dari 223 negara dan yang meninggal karena kasus terpapar covid-19 mencapai 3.899.172 orang (Satuan Tugas Penanganan Covid-19, 2021).

Covid-19 telah berdampak hampir ke semua sektor. Tidak hanya pada sektor Kesehatan tetapi juga berdampak ke sektor Ekonomi maupun sektor Pendidikan. Untuk sektor Pendidikan, Kemendikbud (Kementrian Pendidikan dan Kebudayaan) memiliki kebijakan untuk semua sekolah maupun perguruan tinggi di Indonesia untuk melakukan pembelajaran secara daring atau E-Learning untuk mengurangi penyebaran virus covid-19 di Indonesia. Sistem pembelajaran yang dirubah secara tiba-tiba ini bisa berdampak pada menurunnya minat peserta didik dalam mengikuti pembelajaran (Annur, 2020). Sistem pembelajaran secara daring membawa sebuah masalah baru bagi peserta didik. Peserta didik mengalami stress dalam mengerjakan tugas, dikarenakan peserta didik bingung atas apa yang harus diprioritaskan terlebih dahulu untuk dikerjakan (Mahmudah, 2020). Pembelajaran daring memberikan pengaruh yang kurang baik terhadap psikologis peserta didik. 
Berdasarkan hal tersebut, peneliti tertarik untuk menganalisis peran adversity quotient dengan kemampuan pemecahan masalah matematis peserta didik di masa pandemic covid-19. Tujuan dari penelitian ini adalah menganalisis peran adversity quotient peserta didik kelas VIII SMP tipe climber dalam pemecahan masalah matematis di masa pandemi covid-19.

\section{METODE}

Penelitian yang digunakan adalah penelitian deskriptif kualitatif. Penelitian kualitatif adalah penelitian yang digunakan untuk meneliti objek dalam kondisi yang alamiah (Sugiyono, 2020). Sampel dalam penelitian ini adalah kelas VIII-B di SMP Taman Harapan 1 Bekasi dengan menggunakan teknik stratified random sampling dan purposive sampling. Teknik stratified random sampling digunakan untuk mengelompokkan Adversity Quotient peserta didik berdasarkan tipe climber kategori cukup dan tinggi. Setiap kategori dipilih dua orang sebagai perwakilan. Teknik pengumpulan data menggunakan tes dan non tes. Instrument tes digunakan untuk mengukur kemampuan pemecahan masalah matematis peserta didik pada materi bangun ruang sisi datar, sedangkan instrument non tes menggunakan angket Adversity Quotient yang di adaptasi dari (Hidayat, Herdiman, Aripin, Yuliani, \& Maya, 2018). Pada angket tersebut terdapat lima alternatif pilihan, yang terdiri dari Sangat Setuju (SS), Setuju (S), Netral (N), Tidak Setuju (TS), dan Sangat Tidak Setuju (STS). Instrument penelitian berupa tes uraian terdiri dari 3 soal berdasarkan indikator penskoran kemampuan pemecahan masalah matematis. Adapun pedoman kemampuan pemecahan masalah matematis berdasarkan indikatornya, disajikan pada tabel berikut ini.

Tabel 2. Pedoman Penskoran Kemampuan Pemecahan Masalah

\begin{tabular}{|c|l|c|}
\hline Aspek yang dinilai & \multicolumn{1}{|c|}{ Reaksi Terhadap Soal } & Skor \\
\hline \multirow{5}{*}{ Memahami Masalah } & $\begin{array}{l}\text { Tidak menulis sama sekali apa yang diketahui dan apa yang } \\
\text { ditanyakan. }\end{array}$ & 0 \\
\cline { 2 - 3 } & $\begin{array}{l}\text { Menulis diketahui/ditanyakan/sketsa/model tetapi salah atau } \\
\text { tidak memahami masalah sama sekali. }\end{array}$ & 1 \\
\cline { 2 - 3 } & $\begin{array}{l}\text { Memahami informasi atau permasalahan dengan kurang } \\
\text { tepat/lengkap. }\end{array}$ & 2 \\
\cline { 2 - 3 } $\begin{array}{c}\text { Menyusun Rencana } \\
\text { Pemecahan }\end{array}$ & Berhasil memahami masalah secara menyeluruh. & 3 \\
\cline { 2 - 3 } & $\begin{array}{l}\text { Tidak ada rencana strategi. } \\
\text { tidak/belum jelas. }\end{array}$ & 1 \\
\cline { 2 - 3 } & $\begin{array}{l}\text { Strategi/langkah penyelesaian mengarah pada jawaban yang } \\
\text { benar tetapi tidak lengkap atau jawaban salah. }\end{array}$ & 2 \\
\cline { 2 - 3 } $\begin{array}{c}\text { Melaksanakan } \\
\text { Perencanaan }\end{array}$ & Tidak ada penyelesaiannya sama sekali. & 3 \\
\cline { 2 - 3 } & Ada penyelesaiannya tetapi prosedur tidak jelas/salah & 2 \\
\cline { 2 - 3 } & $\begin{array}{l}\text { Menggunakan prosedur yang benar tetapi perhitungannya } \\
\text { salah/kurang lengkap. }\end{array}$ & 2 \\
\cline { 2 - 3 } & Menggunakan satu prosedur dan jawaban benar. & 4 \\
\cline { 2 - 3 } & $\begin{array}{l}\text { Memberikan jawaban lebih dari satu cara (beragam), proses } \\
\text { perhitungan dan hasil nya benar. }\end{array}$ & 2 \\
\hline
\end{tabular}




\begin{tabular}{|c|l|c|}
\hline \multirow{4}{*}{$\begin{array}{c}\text { Mengevaluasi Hasil } \\
\text { Pemecahan }\end{array}$} & $\begin{array}{l}\text { Jika tidak menuliskan kesimpulan dan tidak melakukan } \\
\text { pengecekan terhadap proses juga hasil jawaban. }\end{array}$ & 0 \\
\cline { 2 - 3 } & $\begin{array}{l}\text { Jika menuliskan kesimpulan dan/atau melakukan pengecekan } \\
\text { terhadap proses dengan kurang tepat }\end{array}$ & 1 \\
Atau & $\begin{array}{l}\text { Jika hanya menuliskan kesimpulan saja atau melakukan } \\
\text { pengecekan terhadap proses saja dengan tepat. }\end{array}$ & \\
\cline { 2 - 3 } & $\begin{array}{l}\text { Jika menuliskan kesimpul dan melakukan pengecekan terhadap } \\
\text { proses dengan tepat }\end{array}$ & 2 \\
\hline
\end{tabular}

Modifikasi (Ariani, Hartono, \& Hiltrimartin, 2017)

Hasil dari tes uraian yang dikerjakan oleh peserta didik akan dikategorikan sesuai kemampuan pemecahan masalah matematis peserta didik seperti pada tabel berikut.

Tabel 3. Kategori Kemampuan Pemecahan Masalah

\begin{tabular}{|c|c|}
\hline Skor & Kategori \\
\hline $\mathbf{7 6 - 1 0 0}$ & Tinggi \\
\hline $\mathbf{6 1 - 7 5}$ & Sedang \\
\hline $\mathbf{0 - 6 0}$ & Rendah \\
\hline
\end{tabular}

(Septianingtyas \& Jusra, 2020)

Metode wawancara yang dilakukan peneliti adalah metode wawancara semistruktur. Peneliti menggunakan metode ini karena peneliti menanyakan kepada peserta didik tentang kemampuan pemecahan masalah matematis sesuai dengan pertanyaan yang akan ditanyakan lalu selanjutnya peneliti akan menanyakan pertanyaan lain berdasarkan jawaban dari subjek agar mendapatkan informasi yang lebih.

\section{HASIL DAN DISKUSI}

Berdasarkan hasil penelitian yang diperoleh, AQ peserta didik dikategorikan berdasarkan pendapat Stoltz (2000). Kategori AQ berdasarkan pendapat Stoltz (2000) ditunjukkan pada berikut.

Tabel 4. Tingkatan Adversity Quotient

\begin{tabular}{|c|c|c|c|}
\hline Adversity Quotient & Kategori & Skor & Jumlah Siswa \\
\hline \multirow{2}{*}{ Climber (Tinggi) } & Tinggi & $166-200$ & 2 \\
\cline { 2 - 4 } & Cukup & $135-165$ & 13 \\
\hline Campers & Sedang & $95-134$ & 8 \\
\hline \multirow{2}{*}{ Quitters (Kurang) } & Kurang & $60-94$ & 0 \\
\cline { 2 - 4 } & Rendah & $0-59$ & 0 \\
\hline
\end{tabular}

Berdasarkan tabel diatas, jika dibuat persentase maka akan menjadi peserta didik dengan AQ tipe climber (tinggi) berjumlah 2 peserta didik dengan persentase 10\%, peserta didik dengan AQ tipe climber (Cukup) berjumlah 13 peserta didik dengan persentase 65\%, lalu untuk peserta didik dengan AQ tipe camper berjumlah 5 peserta didik dengan persentase $25 \%$. Subjek penelitian yang sudah dikelompokkan berdasarkan tipe AQ dipilih 4 subjek berdasarkan tipenya, yaitu 2 peserta didik tipe climber (tinggi) dan 
2 peserta didik tipe climber (cukup). Adapun keempat peserta didik yang menjadi subjek penelitian ditunjukkan pada tabel berikut.

Tabel 4. Daftar Nama Subjek Penelitian

\begin{tabular}{|l|l|}
\hline \multicolumn{1}{|c|}{ Nama Subjek } & \multicolumn{1}{|c|}{ Kelompok } \\
\hline S01 & Climber (Tinggi) \\
\hline S02 & Climber (Tinggi) \\
\hline S03 & Climber (Cukup) \\
\hline S04 & Climber (Cukup) \\
\hline
\end{tabular}

Keempat subjek yang telah dipilih, selanjutnya diberikan tes uraian kemampuan pemecahan masalah matematis pada materi bangun ruang sisi datar. Setelah keempat subjek penelitian tersebut selesai menyelesaikan soal, maka selanjutnya peneliti melakukan wawancara terhadap subjek penelitian yang telah dipilih. Wawancara ini dilakukan untuk mengetahui lebih dalam lagi informasi tentang kemampuan pemecahan masalah matematis peserta didik. Setelah data hasil tes uraian dan hasil wawancara diperoleh, maka selanjutnya peneliti melakukan Analisis terhadap hasil tes uraian dan hasil wawancara.

\section{Kemampuan Pemecahan Masalah Peserta Didik AQ Tipe Climber (Tinggi)}

Berdasarkan hasil penelitian diatas, dapat diketahui bahwa terdapat 2 peserta didik yang memiliki AQ tipe climber kategori tinggi. Peserta didik yang memiliki AQ tipe climber kategori tinggi diberi nama S01 dan S02. Berdasarkan hasil tes menunjukkan bahwa S01 dan S02 memiliki kemampuan pemecahan masalah matematis kategori tinggi. Berikut hasil pengerjaan dari peserta didik yang memiliki AQ tipe climber kategori tinggi dengan kemampuan pemecahan masalah matematis yang tinggi terdapat pada gambar 1 (a) dan 1 (b).

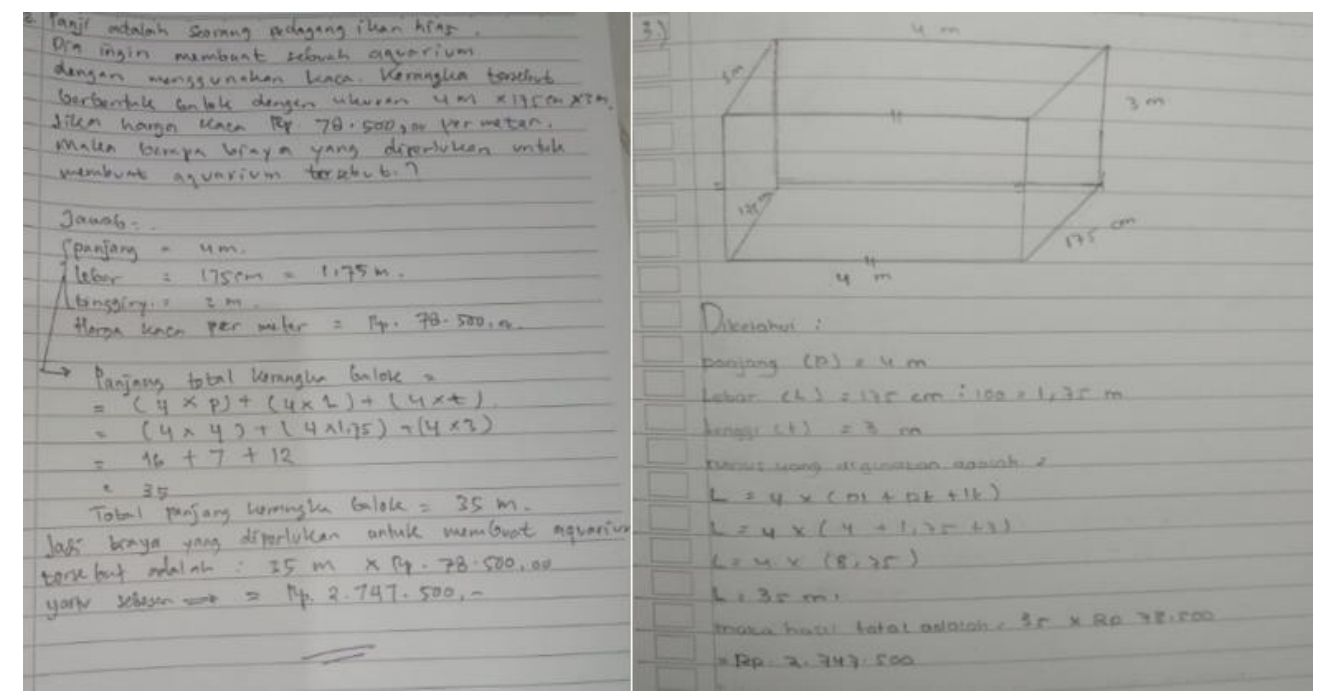

1 (a)

1 (b)

Gambar 1(a) jawaban S01 dan 1(b) jawaban S02 
Berdasarkan jawaban dari S01 dan S02 pada gambar 1 (a) dan 1 (b) dapat diketahui bahwa S01 dan S02 mampu mencapai semua indikator pemecahan masalah. S01 dan S02 memahami permasalahan yang ada pada soal, maka dapat dilihat pada kedua hasil pengerjaan diatas S01 dan S02 menuliskan apa yang dikatehui dan apa yang ditanyakan pada soal. Hal itu, memberitahukan bahwa kedua subjek memahami permasalahan pada soal. Selanjutnya untuk perencanaan strategi kedua subjek menggunakan strategi yang sama. S01 dan S02 menggunakan rumus keliling balok, tetapi S01 tidak menuliskan lambah keliling sebelum menuliskan rumusnya sedangkan S02 melakukan kesalahan pada penulisan lambang untuk rumusnya. S02 menuliskan L yang biasa digunakan untuk melambangkan luas, bukan keliling. Meskipun begitu, kedua subjek tetap memperoleh hasil yang tepat. Setelah mendapatkan hasilnya, kedua subjek menuliskan kesimpulan dari permasalahan pada soal tersebut. Berdasarkan hasil wawancara yang dilakukan menggunakan aplikasi zoom meeting, kedua subjek tersebut mampu menjelaskan cara untuk menyelesaikan soal tersebut. S01 dan S02 memahami apa permasalahan pada soal tersebut sehingga kedua subjek menjelaskan bahwa cara untuk menyelesaikan permasalahan pada soal yaitu dengan cara menghitung ukuran keliling aquarium yang berbentuk balok terlebih dahulu. Saat merencanakan strategi, S02 mengaku bahwa sebelumnya S02 menggunakan rumus luas balok untuk menghitung ukuran kerangka aquarium tetapi saat S02 membaca lagi soal tersebut dengan teliti, S02 paham bahwa yang seharusnya dihitung adalah keliling aquarium yang berbentuk balok bukan luas aquariumnya. Oleh karena itu, S02 mengganti jawaban sebelumnya menjadi jawaban yang seharusnya, tetapi saat mengganti rumusnya, S02 lupa untuk mengganti lambang luas menjadi keliling. Lalu ketika sudah diketahui ukuran baloknya maka langkah selanjutnya yaitu menghitung biaya untuk membuat kerangka aquariumnya dan langkah terakhir yaitu membuat kesimpulan.

Berdasarkan hasil pengerjaan S01 dan S02 dapat disimpulkan bahwa S01 dan S02 yang memiliki AQ tipe climber kategori tinggi dan memiliki kemampuan pemecahan masalah matematis yang tinggi juga. Saat dihadapi soal pemecahan masalah S01 dan S02 mampu menyelesaikannya dengan tepat dan teliti walaupun hanya dengan satu strategi saja. S01 dan S02 juga mampu mencapai indikator kemampuan pemecahan masalah matematis berdasarkan teori polya. Hal ini sesuai dengan hasil penelitian (Aini \& Mukhlis, 2020) yang menyatakan bahwa peserta didik dengan AQ tipe climber mencapai semua indikator pemecahan masalah berdasarkan teori polya. Walaupun S02 melakukan sedikit kesalahan karena lupa untuk merubah lambang luas balok menjadi keliling, tetapi S02 menyadari kesalahannya.

\section{Kemampuan Pemecahan Masalah Peserta Didik AQ Tipe Climber (Cukup)}

Berdasarkan hasil penelitian yang dilakukan terdapat 13 peserta didik yang memiliki AQ tipe climber kategori cukup dan hanya 2 peserta didik yang diambil sebagai perwakilan AQ tipe climber (cukup). Peserta didik yang diambil sebagai perwakilan AQ tipe climber kategori cukup dinamakan sebagai S03 dan S04. Berdasarkan hasil yang didapat S03 memiliki kemampuan pemecahan masalah matematis yang tinggi. Sedangkan S04 memiliki kemampuan pemecahan masalah matematis yang 
sedang. Berikut hasil pengerjaaan peserta didik dengan AQ tipe climber kategori cukup dengan kemampuan pemecahan masalah matematis yang tinggi dan sedang pada soal nomor 3 terdapat pada gambar 2 (a) dan 2 (b).

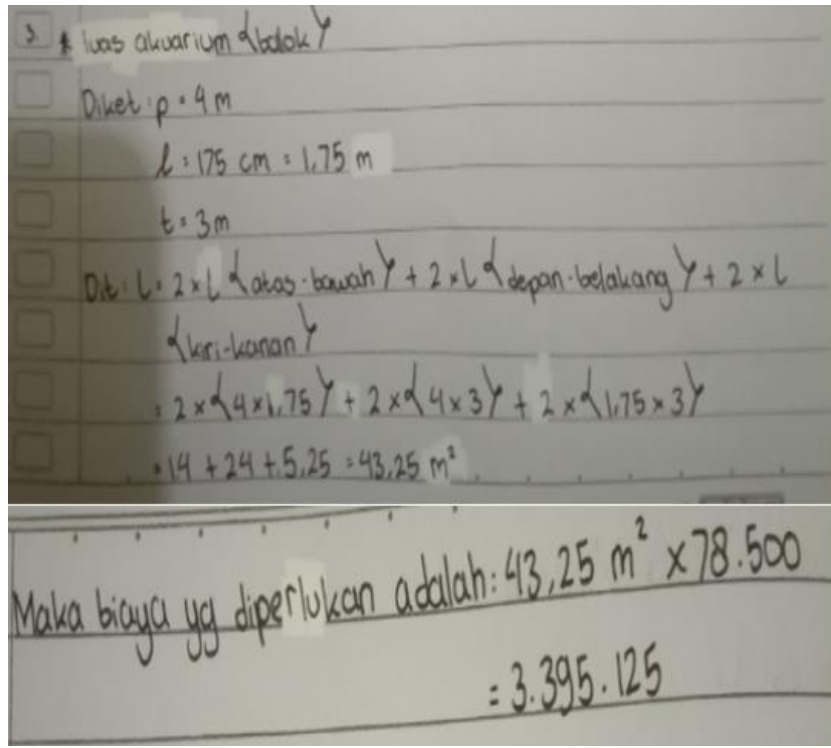

2 (a)

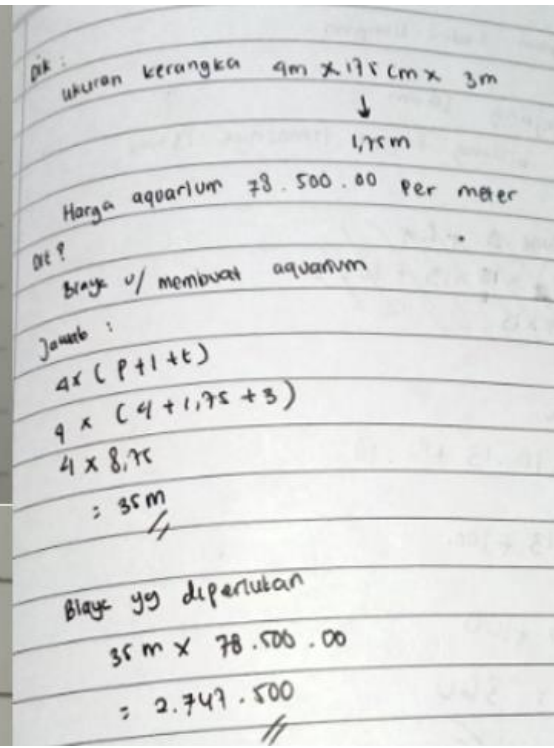

2 (b)

Gambar 2 (a) jawaban S03 dan 2 (b) jawaban S04

Berdasarkan gambar 2 (a) dan 2 (b), bisa dilihat bahwa S03 dan S04 juga mengerjakan soal sesuai dengan indikator pemecahan masalah matematis hanya saja S03 melakukan kesalahan saat merencanakan strateginya untuk menyelesaikan masalah pada soal. Sehingga S03 menggunakan strategi yang kurang tepat dalam menyelesaikan pemecahan masalah. S03 juga tidak mengecek kembali hasil yang didapat yang mengakibatkan hasilnya berbeda dengan yang seharusnya. Sejalan dengan hasil penelitian (Hutami, Trapsilasiwi, \& Murtikusuma, 2020) yang menyimpulkan bahwa peserta didik dengan AQ tipe climber mengalami kesalahan dalam memecahkan permasalahan pada soal. Meskipun begitu S03 tetap berusahan menyelesaikan soal tersebut hingga menemukan hasil akhirnya. Jika S03 melakukan kesalahan, maka S04 sebaiknya, S04 tidak melakukan kesalahan. S04 mampu menuliskan semua indikator pemecahan masalah tanpa ada kesalahan. Hanya saja seperti peserta didik lainnya, S04 hanya menggunakan satu strategi untuk menyelesaikannya. S04 tidak menuliskan strategi lain untuk menyelesaikan masalah pada soal tersebut. Berdasarkan wawancara yang telah dilakukan, S03 dan S04 mampu menjabarkan jawabannya untuk memecahkan soal tersebut. S03 dan S04 menjelaskan dengan sangat baik sesuai dengan jawaban yang ditulisnya. Tetapi S03 tidak menyadari kesalahannya dalam menggunakan strategi untuk memecahkan masalah pada soal tersebut. Sedangkan S04 mampu menjelaskan setiap pengerjaan yang dia lakukan sesuai indikator kemampuan pemecahan masalah dan sesuai dengan hasil yang S04 tulis. S04 memahami permasalahan pada soal, sehingga S04 menuliskan apa yang diketahui dan apa yang ditanyakan pada soal. Lalu S04 menjelaskan apa yang akan dilakukan untuk menyelesaikan soal tersebut. S04 menjelaskan bahwa untuk menyelesaikan soal yang memiliki masalah seperti soal nomor 3 cara menyelesaikannya dengan menggunakan rumus keliling balok untuk 
mengetahui ukuran kerangka aquarium lalu selanjutnya S04 menjelaskan bahwa setelah mendapatkan ukuran dari kerangkan aquarium tersebut maka selanjutnya menghitung biaya yang dikeluarkan untuk membuat kerangka aquarium tersebut. S04 juga mampu membuat kesimpulan dari soal tersebut.

Berdasarkan hasil pengerjaan S03 dan S04 dapat diketahui bahwa walaupun S04 memiliki kemampuan pemecahan masalah yang sedang tetapi S04 mampu menyelesaikan soal nomor 3 dengan tepat. Sedangkan S03 walaupun memiliki kemampuan pemecahan masalah yang tinggi tetapi S03 melakukan kesalahan dalam merencanakan strategi pemecahan masalahnya pada soal nomor 3 dan S03 tidak mengecek kembali strategi dan hasil yang didapat, apakah sudah tepat atau belum. Sehingga S03 mendapatkan hasil akhir yang kurang tepat.

\section{Peran AQ Tipe Climber dalam Pemecahan Masalah Matematis}

Berdasarkan hasil yang didapat, peserta didik dengan AQ tipe climber memiliki kemampuan pemecahan masalah yang tinggi hanya saja peserta didik dengan AQ tipe climber terkadang mengalami kesalahan dalam menyelesaikan soal pemecahan masalah, meskipun begitu peserta didik dengan AQ tipe climber akan berusaha untuk mendapatkan hasil akhir walaupun mengalami kesulitan ketika menghadapi soal pemecahan masalah. Sejalan dengan pendapat (Mardika \& Insani, 2017) yang menyatakan bahwa seseorang yang memiliki tingkat AQ yang tinggi maka memiliki kemampuan pemecahan masalah yang tinggi pula, dan hal ini juga sesuai dengan penelitian (Rosita, 2016) bahwa peserta didik dengan AQ tipe climber saat menyelesaikan masalah matematika akan berusaha untuk bisa menyelesaikan masalah tersebut walaupun mengalami kesulitan. Berdasarkan hasil penelitian bahwa peserta didik dengan AQ tipe climber memenuhi semua indikator pemecahan masalah menurut polya. Hal ini, sesuai dengan hasil penelitian (Septianingtyas \& Jusra, 2020) yang menyatakan bahwa peserta didik dengan tipe climber mampu melaksanakan tahapan kemampuan pemecahan masalah matematis menurut polya dengan sangat baik, oleh sebab itu peserta didik dengan AQ tipe climber akan memperoleh skor yang maksimal disetiap soal yang sedang dihadapinya. Hal tersebut dapat diketahui bahwa tingkat AQ seseorang sangat penting untuk memecahkan soal matematis. Peserta didik dengan AQ tipe climber akan memperoleh hasil belajar yang maksimal karena para climber tidak akan pantang menyerah saat dihadapi masalah dalam hidupnya, para climber akan berusaha untuk mencapai kesuksesannya dengan menghadapi hambatan dalam hidupnya (Abdiyani et al., 2019).

\section{KESIMPULAN}

Berdasarkan hasil penelitian yang sudah dilakukan, peneliti dapat menyimpulkan bahwa peserta didik dalam memecahkan soal matematis memiliki berbagai macam cara berdasarkan kemampuannya dalam memecahkan suatu permasalahannya dan juga berdasarkan tingkat adversity quotient masingmasing peserta didik. Kelas yang dijadikan sebagai sampel penelitian menunjukkan bahwa peserta didiknya rata-rata memiliki AQ tipe climber. Peserta didik dalam kelas tersebut memiliki daya juang yang tinggi, tidak akan menyerah saat dihadapi masalah dalam hidupnya. Berdasarkan hasil penelitian terdapat 15 peserta didik dengan AQ tipe climber dan sisanya yaitu 5 peserta didik memiliki AQ tipe 
camper. 15 peserta didik yang memilik AQ tipe climber memiliki kategori yang berbeda-beda, terdapat 2 peserta didik dengan AQ tipe climber kategori tinggi dan 13 peserta didik dengan AQ tipe climber kategori cukup. Berdasarkan kemampuan pemecahan masalah matematis peserta didik yang dipilih menjadi subjek, dari 4 peserta didik yang memiliki AQ tipe climber terdapat 3 peserta didik yang memiliki kemampuan pemecahan masalah yang tinggi dan terdapat 1 orang yang memiliki kemampuan pemecahan masalah matematis yang sedang. Peneliti menyimpulkan bahwa AQ tipe climber peserta didik memiliki peranan penting dalam kemampuan pemecahan masalah matematis apalagi di masa pandemi seperti saat ini.

Peneliti menyarankan untuk guru diharapkan mampu memberikan soal tentang permasalahan matematis saat pembelajaran. Hal tersebut agar peserta didik lebih berpengalaman untuk mengerjakan soal matematis yang berkaitan dengan permasalahan dan hal itu juga akan memberikan perkembangan untuk tingkat kemampuan pemecahan masalah matematis peserta didik.

\section{UCAPAN TERIMA KASIH}

Puji dan syukur saya ucapkan terimakasih kepada Allah SWT yang telah melancarkan saya dalam menyusun artikel ini, kemudian saya ucapkan terimakasih kepada keluarga saya yang telah mendoakan dan mendukung saya dalam penulisan artikel ini, selanjutnya saya ucapkan terimakasih kepada dosen pembimbing saya yang telah membantu dan membimbing saya selama menulis artikel ini dan saya ucapkan terimakasih juga kepada seluruh dosen Pendidikan Matematika Universitas Muhammadiyah Prof. Dr. Hamka, serta saya ucapkan terimakasih kepada SMP Taman Harapan 1 Bekasi yang telah mengizinkan saya untuk melaksanakan penelitian di tempat tersebut.

\section{REFERENSI}

Abdiyani, S. S., Khabibah, S., \& Rahmawati, N. D. (2019). Profil Kemampuan Pemecahan Masalah Matematika Siswa SMP Negeri 1 Jogoroto Berdasarkan Langkah-langkah Polya Ditinjau dari Adversity Quotient. Al-Khwarizmi: Jurnal Pendidikan Matematika Dan Ilmu Pengetahuan Alam, 7(2), 123-134. https://doi.org/10.24256/jpmipa.v7i2.774

Aini, N. N., \& Mukhlis, M. (2020). Analisis Kemampuan Pemecahan Masalah Pada Soal Cerita Matematika Berdasarkan Teori Polya Ditinjau Dari Adversity Quotient. Alifmatika: Jurnal Pendidikan Dan Pembelajaran Matematika, 2(1), 105-128. https://doi.org/10.35316/alifmatika.2020.v2i1.105-128

Annur, M. F. (2020). Analisis kesulitan mahasiswa pendidikan matematika. Jurnal Kajian, Pnelitian Dan Pengembangan Kependidikan, 6356, 195-201.

Ariani, S., Hartono, Y., \& Hiltrimartin, C. (2017). Kemampuan Pemecahan Masalah Matematika Siswa pada Pembelajaran Matematika Menggunakan Strategi Abduktif-Deduktif di SMA Negeri 1 Indralaya Utara. Jurnal Elemen, 3(1), 25. https://doi.org/10.29408/jel.v3i1.304 
Asmuni. (2020). Problematika Pembelajaran Daring di Masa Pendemi Covid-19 dan Solusi Pemecahannya. Jurnal Paedagogy: Jurnal Penelitian Dan Pengembangan Pendidikan, 7(4), 281288. https://doi.org/https://doi.org/10.33394/jp.v7i4.2941

Eviyanti, C. Y., Surya, E., Syahputra, E., \& Simbolon, M. (2017). Improving the Students' Mathematical Problem Solving Ability by Applying Problem Based Learning Model in VII Grade at SMPN 1 Banda Aceh Indonesia. International Journal of Novel Research in Education and Learning, 4(2), 138-144. Retrieved from https://www.researchgate.net/publication/318529138

Hanifah, hilmi R. F. N., \& Nuraeni, R. (2020). Perbedaan Peningkatan Kemampuan Pemecahan Masalah Matematis Siswa antara Think Pair Share dan Think Talk Write. Mosharafa: Jurnal Pendidikan Matematika, 9(1), 155-166. Retrieved from https://journal.institutpendidikan.ac.id/index.php/mosharafa/article/viewFile/mv9n1_14/564

Hidayat, W., Herdiman, I., Aripin, U., Yuliani, A., \& Maya, R. (2018). Adversity Quotient (AQ) dan Penalaran Kreatif Matematis Mahasiswa Calon Guru. Jurnal Elemen, 4(2), 230. https://doi.org/10.29408/jel.v4i2.701

Hutami, F. E., Trapsilasiwi, D., \& Murtikusuma, R. P. (2020). Analisis Kesalahan Siswa Dalam Menyelesaikan Soal Program Linear Ditinjau Dari Adversity Quotient. Alifmatika: Jurnal Pendidikan Dan Pembelajaran Matematika, 2(1), 1-13. https://doi.org/10.35316/alifmatika.2020.v2i1.1-13

Isnaini Handayani, \& Afifah Fitria Ramadhani. (2020). Analisis Kemampuan Pemahaman Konsep Matematis Peserta Didik Ditijau Dari Adversity Quotient. Buana Matematika: Jurnal Ilmiah Matematika Dan Pendidikan Matematika, 10(1), 43-60. https://doi.org/10.36456/buanamatematika.v10i1.2442

Juwita, H. R., Roemintoyo, \& Usodo, B. (2020). Peran Adversity Quotient di Bidang Pendidikan: Tinjauan tentang Sastra tentanf Perkembangan Pendidikan. Jurnal Internasional Metodologi Pendidikan, 6(3), 507-515. https://doi.org/doi: 10.12973 / ijem.6.3.507

Mahmudah, S. R. (2020). Pengaruh Pembelajaran Daring terhadap Psikologis Siswa Terdampak Social Distancing Akibat Covid 19. Jurnal Al-Mau'izhoh, 2(2), 1-14.

Mardika, F., \& Insani, S. U. (2017). Adversity Quotient and Students 'Problem Solving Skill in Mathematics. 4th ICRIEMS Proceedings, 21-26.

Naimnule, M., Kartono, \& Asikin, M. (2020). Mathematics Problem Solving Ability in Terms of Adversity Quotient in Problem Based Learning Model With Peer Feedback. Unnes Journal of Mathematics Education Research, 10(2), 222-228. Retrieved from http://journal.unnes.ac.id/sju/index.php/ujmer

NCTM. (2000). Pssm. Journal of Equine Veterinary Science, 18(11), 719. 
https://doi.org/10.1016/s0737-0806(98)80482-6

Nuramalina, Y., Hendrayana, A., \& Khaerunnisa, E. (2020). Analisis Kemampuan Pemecahan Masalah Siswa Melalui Aktivitas Rigorous Mathematical Thinking Ditinjau Dari Kemampuan Awal Dan Gaya Belajar. Jurnal Penelitian Pembelajaran Matematika, 13(1), 133-149.

OECD. (2019). Programme for international student assessment (PISA) results from PISA 2018. Oecd, 1-10. Retrieved from https://www.oecd-ilibrary.org/education/pisa-2018-results-volumeiii_bd69f805-en\%0Ahttps://www.oecd-ilibrary.org//sites/bd69f805-

en/index.html?itemId=/content/component/bd69f805-en\#fig86

Purwasih, R. (2019). KEMAMPUAN BERPIKIR KREATIF MATEMATIS SISWA SMP DALAM MENYELESAIKAN SOAL PEMECAHAN MASALAH DITINJAU DARI ADVERSITY QUOTIENT TIPE CLIMBER. AKSIOMA: Jurnal Program Studi Pendidikan Matematika, 8(2), 323-332. https://doi.org/https://doi.org/10.24127/ajpm.v8i2.2118

Rosita, D. (2016). Analisis Kesalahan Siswa dalam Pemecahan Masalah ditinjau dari Adversity Quotient pada Pembelajaran Creative Problem Solving. Unnes Journal of Mathematics Education Research, 5(2), 106-113.

Septianingtyas, N., \& Jusra, H. (2020). Kemampuan Pemecahan Masalah Matematis Peserta Didik Berdasarkan Adversity Quotient. Jurnal Cendekia : Jurnal Pendidikan Matematika, 4(2), 657672. https://doi.org/10.31004/cendekia.v4i2.263

Stoltz, P., \& (Penerjemah), T. H. (2018), Adversity Quotient Mengubah Hambatan Menjadi Peluang (Y. Hardiwati, ed.), Jakarta: PT Grasindo.

Sugiyono. 2020. Metode Penelitian Kualitatif. Bandung: Alfabeta.

Widyastuti, R. (2015). Proses Berfikir Siswa dalam Menyelesaikan Masalah Matematika berdasarkan Teori Polya ditinjau dari Adversity Quotient Tipe Climber. Al-Jabar: Jurnal Pendidikan Matematika, 6(2), 183-194. Retrieved from http://ejournal.radenintan.ac.id/index.php/aljabar/article/view/48/0

Yanti, A. P., Koestoro, B., \& Sutiarso, S. (2018). The Students' Creative Thinking Process based on Wallas Theory in Solving Mathematical Problems viewed from Adversity Quotient /Type Climbers. Al-Jabar: Jurnal Pendidikan Matematika, $9(1), \quad 51$. https://doi.org/10.24042/ajpm.v9i1.2331. 